\title{
EVALUATION OF THE EFFECT OF A COMPUTER-BASED TEACHING PROGRAMME (CBTP) ON KNOWLEDGE, PROBLEM-SOLVING AND LEARNING APPROACH
}

\author{
Annemarie Joubert \\ $\mathrm{PhD}$ \\ School of Nursing, University of the Free State \\ Corresponding author: gnvkaj@med.uovs.ac.za

\section{Marlene J Viljoen} \\ DSocSc \\ School of Nursing, University of the Free State

\section{Jacobus A Venter} \\ $\mathrm{PhD}$ \\ School of Nursing, University of the Free State
}

\section{Catharina J Bester}

BSc Hons (Mathematical statistics)

School of Nursing, University of the Free State

Keywords: Knowledge; Learning; Learning approaches; Problem-solving; Computer-based Training Programme (CBTP)

\section{SAMEVATTING}

Eerstens word aandag gegee aan die effek van 'n rekenaargebaseerde onderrigprogram (RGOP) op studentverpleegkundiges se kennis, probleemoplossingsvaardighede en leerbenadering. Tweedens word die benutting van die RGOP deur respondente ondersoek. Hoogs beduidende tot beduidende statistiese verbetering in kennis het volgens die Wilcoxon se teken rangtoets, en nie-parametriese vertrouensintervalle vir al die groepe behalwe die kontrole groep (praktyk) voorgekom. Alhoewel statisties betekenisvolle verskille nie ten opsigte van probleemoplossing voorgekom het nie, het die respondente se punte op hulle posttoetse tog ' $n$ verbetering getoon. In die praktyk is geen statisties beduidende verandering in respondente se leerbenadering na benutting van die RGOP gevind nie. Geringe verskille ten opsigte van die verskillende kategorieë van leerbenaderinge (betekenis, reproduksie, nie-akademies en strategies) is wel gevind. Die multimediarekenaarsentrum groep (MMS groep) het oor die algemeen meer as die praktykgroep van die RGOP gebruik gemaak. Die mediaan sessies was 3 (praktyk) en 12 (MMS). Die verskil wat voorgekom het kan moontlik toegeskryf word aan die feit dat die MMS groep onder baie streng gekontroleerde omstandighede die navorsing voltooi het. Die mate waartoe die praktykgroep die RGOP benut het, kon moontlik deur interne faktore soos byvoorbeeld ' $n$ tekort aan personeel, pasiëntladings, die verpleegsorgbehoeftes van pasiënte veroorsaak gewees het. Dit wil voorkom of die RGOP wat ontwikkel was met die doel om kennis in verband met onkologiese verpleegsorg te verbeter, wel effektief gebruik kan word. Na aanleiding van al die resultate, word egter aanbeveel dat rekenaargebaseerde onderrig nie in isolasie gebruik moet word om bepaalde vaardighede by studente te ontwikkel nie, maar deel van 'n saamgestelde onderrigpakket moet vorm. 
In the first instance attention is paid to the effect of a computer-based teaching programme (CBTP) on the knowledge, problem-solving skills and learning approach of student nurses. Secondly, the utilisation of a CBTP by respondents is investigated. Highly significant to significant statistical improvement in knowledge took place according to the Wilcoxon's sign rank test and non-parametric confidence intervals for all groups except the control group (practice). Although problem-solving did not reveal statistically significant differences, the marks of the respondents for their post-test did show improvement. In the practice group (oncology wards) no statistically significant change in the learning approach of respondents was found after using the CBTP. Slight differences were, however, found in the different categories of learning approaches (meaning, reproduction, non-academic and strategic). On the whole the multimedia computer centre group (MMC group) made more use of the CBTP than the practice group. The median sessions were 3 (practice) and 12 (MMC). The difference may possibly be ascribed to the fact that the MMC group completed the research under very strictly controlled circumstances. The degree to which the practice group utilised the CBTP may have been due to internal factors such as staff shortage, case loads, and the nursing care needs of patients. It would appear that the CBTP that was developed with the aim of improving knowledge of oncological nursing can, in fact, be effectively used. However, in view of all the results, computer-based teaching is not recommended to be used in isolation to develop specific skills in students, but that it should form part of a combined teaching package.

\section{INTRODUCTION}

Until recently the principles of learning proposed by mainstream psychology, were used as a basis for the learning process at institutions for higher education. However, the problem was that the research on which these learning principles were based was mainly carried out in a laboratory and artificial or over-simplified learning material was used to describe or explain learning and learning processes. Attempts to apply these findings to teaching in the classroom failed and, especially since 1975 , efforts were directed to develop principles based on the experience of students in university courses (Entwistle, 1984; Entwistle \& Meyer, 1992).

\section{LITERATURE REVIEW}

Whereas traditional research into learning attempted to describe the learning behaviour of learners through objective observation, the alternative approach to learning is aimed at forming an empathetic understanding of how learners learn by establishing which skills they develop during the learning process (Newble \& Entwistle, 1986; Lyons, Miller \& Milton, 1998). This approach necessarily resulted in the adaptation of the methodology of training and in a different approach to the learning process of learners (Entwistle, 1984; McKane \& Schumacher, 1997:88-91; Manias, Bullock
\& Bennett, 1999:23-29; Bove, 2000:73-81; Manias, Bullock \& Bennett, 2000:265-271).

\section{Learning approaches}

The various approaches to learning discussed in the literature include atomistic, superficial, holistic, deep and strategic. The Lancaster learning approach and course evaluation questionnaire are used to measure all the orientations on the basis of certain aspects.

\section{Atomistic vs superficial approach}

According to Marton and Säljo (1984), Svensson (1976) describes the variations in cognitive approach as holistic and atomistic. In following the atomistic approach to learning, the learner focuses on specific comparisons in the content, on the sequence, but not on the main parts, details are memorised and the learner shows no insight.

With the superficial approach, learners try to memorise content, which they identify as being important (Entwistle, 1981; Marton \& Säljo, 1984). With this approach the learner does not manage to appreciate the structure and principles of the subject matter, and therefore effective learning does not take place. Learners memorise in an attempt to remember facts especially when they are of the opinion that this is what is ex- 
pected of them. Learners are mainly motivated in this case to complete the course (Martenson, 1986:532534; Newble \& Entwistle, 1986).

\section{Holistic vs deep approach}

Learners with a holistic approach to learning try to understand the content as a whole, want to know what the author is trying to tell the reader, and attempt to link the content to the greater whole (Marton \& Säljo, 1984).

The characteristics of the deep approach to learning correspond to the above approach. The predominant motivation for this approach to learning is a keen interest in the subject-content and a search for the content's relevance to the profession. An effort is made to gain understanding. Learners show an active approach to a learning task and aim to integrate new ideas with existing knowledge and personal experiences (Martenson, 1986:532-534).

Not all learners follow a constant approach to learning. When necessary, the deep or superficial approach is used. The secret seems to be that learners must be able to follow both approaches (Newble \& Entwistle, 1986).

\section{Strategic vs deep and superficial ap- proach}

The most important motivation for learners who follow the strategic approach is to achieve points or symbols. The element of competition, which also serves as motivation, and the fact that learners make use alternately of the deep and superficial approach, is typical of this approach. The learners' study methods are well organised and this in turn is linked to motivation and the determination to achieve (Entwistle \& Meyer, 1992). Unlike the students who follow the deep approach, these students are much more influenced by the content/context than by the nature of the task. It may be difficult to distinguish students with this approach from those who follow a deep or superficial approach. Students usually use the approach that will most possibly lead to successful study (Newble \& Entwistle, 1986).

In a comparison between the holistic/deep and atomistic/superficial approaches in respect of success, the opinion is given that the holistic approach is not a prerequisite for successful studies. Learners who com- bine an atomistic approach with hard work are just as successful as learners who follow a holistic approach. If the aim is to understand the content, the holistic/ deep approach seems to be the only successful method (Marton \& Säljo, 1984).

\section{Cognitive (knowledge) and problem-solv- ing skills}

Cognitive (knowledge) and problem-solving skills important for nursing are emphasised in the education and training of student nurses, and promoted by the implementation of a variety of training strategies.

Intellectual behaviour that represents the cognitive domain includes knowledge, comprehension (understanding), application, analysis, synthesis and evaluation. The knowledge leve/ represents the lowest level of the cognitive domain and requires mainly that students be able to recall previous knowledge. To apply existing knowledge requires a high level of thinking of students. The ability to analyse lies on a higher level than both knowledge and application. Two other cognitive skills that are important in the teaching situation are the ability to synthesize and evaluate content. Synthesis comprises the linking of parts to form a new whole. Evaluation is viewed as the highest level of the cognitive hierarchy (Van Hoozer, Bratton, Ostmoe, Weinholtz, Craft, Gjerde \& Albenese, 1987:21-22).

Problem-solving refers to the way in which individuals use existing knowledge, skills and understanding in order to understand unfamiliar situations. Problemsolving is thus regarded as a process and the skills to use the process must be acquired (Krulik \& Rudnick, 1984).

The process of general problem-solving in clinical health care service is often described by concepts such as clinical methods, clinical judgement, diagnostic skills or clinical reasoning skill (Norman, Tugwell, Feightner, Muzzin \& Jacoby, 1985:344-356; Norman, 1988:279286). According to Krulik and Rudnick (1984), the process problem-solving consists of five steps, but contrary to this, Ridderikhoff (1991:196-207) mentions that the way in which problems are solved in health care services is still uncertain.

It also seems that this process is not readily learned, and that students tend to learn the process and the 
problem-solving skill only once they practice and are confronted with real problems (Tuma \& Reif, 1980:4).

Dependent on this, modern cognitive psychology drew the attention of university lecturers to the importance of understanding and meaning rather than recognition and reproduction as a learning aim (Marton, Hounsell \& Entwistle, 1984). Although problems with the application of new theories are still experienced due to the distinctive characteristics of each field of study, research findings in this respect are increasingly accepted (Entwistle \& Meyer, 1992; Lyons, Miller \& Milton, 1998:35-39; Boucher, Hunter \& Henry, 1999:47-51).

\section{PROBLEM STATEMENT}

With the aim of better utilising learning opportunities for student nurses, inquiries were made into alternative teaching methods and techniques. The development and implementation of a CBTP were considered as an opportunity to promote the knowledge, problemsolving skills and learning approach of student nurses. However, the value and success of this teaching method had to be established.

A review of the literature revealed that most research evaluates the effectiveness of computer-based teaching in respect of gaining and retaining knowledge. In order to address a limited approach to evaluation, this study, unlike many others, focuses on the effect on knowledge, problem-solving, learning approaches and the extent to which the CBTP is used by students.

\section{CONCEPTS}

\section{Computer-based teaching}

Computer-based teaching encompasses all activities in which computer systems are used in training, including the training process, namely record-keeping and evaluation of students' progress (Saba \& McCormick, 1986:362).

The researcher uses the concept computer-based teaching to refer to all computer teaching programmes, including, among others, self-directed learning, own learning rate, interaction between computer and student and the hierarchical structuring of content.

Computer-based teaching programme (CBTP)
The CBTP is a learning programme developed by the researcher for student nurses in an oncology clinical setting. It was developed in such a way that its use will promote students' cognitive and problem-solving skills, as well as a deep active approach to learning.

\section{Learning approach}

The concept learning approach is used, according to Marton and co-workers (1984:43), to describe two differentiated forms of understanding, that is, deep/superficial and atomistic/holistic understanding.

The deep approach leads to a more comprehensive understanding of content, better retention and greater success in examinations (Newble \& Entwistle, 1986:164, 171). A superficial approach indicates a process whereby the students attempt to memorise content that they identify as being important (Entwistle, 1981:77; Marton \& Säljo, 1984:36-46).

\section{Knowledge}

Human behaviour is classified by educational psychologists such as Bloom and Krathwohl as cognitive, affective and psychomotor (Van Hoozer, et al. 1987). The cognitive domain includes knowledge, comprehension (understanding), application, analysis, synthesis and evaluation. The knowledge level is the lowest level of the cognitive domain in which students should be able to recall previous knowledge. Knowledge therefore forms the basis necessary to understand what has been learned. Evaluation is viewed as the highest level of the cognitive hierarchy. All the cognitive categories are included in the process of evaluation (Van Hoozer, et al. 1987:21-22).

\section{Learning}

The assumptions that constructivists make about learning and that are takern into account in the development of computer programmes, include, among others that learning takes place by the linking of facts and events; that learning is a human process, requires human intervention and is therefore cooperative in nature (Cronje, 1994:47-50).

\section{Problem-solving}

Problem-solving is the manner in which individuals use existing knowledge, skills and comprehension to understand unknown situations. Problem-solving is therefore viewed as a process and the skills to use the pro- 
cess must be taught. The process of general problemsolving is often described by concepts such as clinical methods, clinical judgment, diagnostic skills or clinical reasoning skill (Krulik \& Rudnick, 1984:4; Norman, et al. 1985:344; Norman, 1988:280).

\section{AIM \& OBJECTIVES OF THE RESEARCH}

This research was aimed at evaluating the effect of a computer-based teaching programme (CBTP) on knowledge, problem-solving skills and learning approach. More specifically the objectives were to evaluate its effect by establishing whether:

- student nurses knowledge and problem-solving skills improved;

- computer-based teaching influenced learning approaches; and

- to assess the utilisation of the CBTP by student nurses

\section{COURSE OF THE RESEARCH}

In order to achieve the objectives of the research, a comparative and descriptive study with an experimental, pre-test-post-test control group design was used to evaluate the effect of the computer-based teaching programme. It was also important to exercise a degree of control over the variables.

A literature review and different measuring instruments were used as research techniques.

The research was divided into two stages. In stage $1 \mathrm{a}$ CBTP was developed and evaluated while implementation and data gathering took place in stage 2. To implement the CBTP two separate samples were taken. One group utilised the CBTP in clinical practice and the other group under strictly controlled circumstances, that is, within a timeframe of six hours in a multimedia centre. Both groups were divided into control and experimental groups. Respondents were informed about the research and various pre-tests were done. Data were also gathered through post-tests and a computer programme designed specifically for this purpose.

\section{RESEARCH SETTING}

The research was carried out in two different settings, namely a nursing practice setting and under strictly controlled circumstances in a multimedia computer centre.

\section{The nursing practice setting}

The Oncology Department comprises various sections, for instance a clinic, a radiotherapy and research section, and four nursing sections. The four nursing sections or wards were easily accessible.

As the CBTP had to be installed on computers in the wards, the available facilities were important. Three wards had the required computer facilities, which were linked to a central network. At least three computers were required for the research and as only two were linked to a network, provision had to be made for a third computer that could function independently of the network. The two computers in the wards were available in the duty room, and within reach of the respondents that were included in the research group. The third computer, which was purchased for the purpose, was installed in a separate suitable room. The main requirement was free access to the CBTP.

\section{The multimedia computer centre}

The multimedia computer centre is situated in the Department of Nursing and is equipped with 18 computers. The CBTP was loaded onto all these computers. In addition the centre has two simulation laboratories and several group session rooms.

\section{SAMPLES}

The target population for the research consisted of student nurses registered for the generic program in nursing at a nursing college and a university respectively.

\section{Sample size}

Factors taken into account for the assessment of the size of the samples in this study were the type of study, the nature of the measuring instruments and the techniques of data analysis. A number of psychometric tests were used in the research, and the opinion of an expert was obtained for the specific sample size. The total sample consisted of one hundred and twenty (120) students. 
Sampling of students or research in clinical nursing practice (oncology wards) (practice group)

Students in their first and/or second year of study at the two nursing education institutions were placed in oncology wards for clinical experience. A convenience selection was done. Inclusion criteria for these respondents were that they had to be placed in an oncology ward for a two-month period.

The sample comprised eighty (80) students, 40 of who were placed in an experimental group and 40 in a control group.

\section{Sampling of students for participation under strictly controlled circumstances in the multimedia computer centre (MMC group)}

Only students registered for the generic degree in nursing were included in the group, as the facilities required for the implementation of the research were available in the school of nursing's multimedia centre at the university. This sampling was also based on convenience selection. First-, second- and third-year students were given the opportunity to take part as volunteers in the research.

Careful consideration was given to the inclusion of third year students. According to the researcher the selection of respondents from different years groups did not pose a problem to the reliability or validity of the research. This was based on the fact that all students were exposed to a computer-based programme especially designed for the oncology clinical setting, for the first time and the fact that respondents had at that stage been exposed to oncology nursing for a period of only two months. Content regarding oncology nursing and placement in the oncology wards are presented at different stages of training in the two institutions involved.

The sample comprises forty (40) students, 20 of who were placed in the experimental group and 20 in the control group.

\section{VALUE OF THE STUDY}

The research findings may possibly contribute to the development of more CBTP's for clinical practice and to programmes being focused on a variety of skills such as knowledge, problem-solving and a deep approach to learning.

\section{ETHICAL ISSUES}

All research was approved by an ethics committee and therefore had to conform to the guidelines.

\section{HYPOTHESES FOR THE RESEARCH}

\section{Nil hypothesis 1:}

Computer-based teaching does not improve knowledge of oncology nursing.

\section{Nil hypothesis 2:}

Computer-based teaching does not improve problemsolving skills.

\section{Nil hypothesis 3:}

Computer-based teaching does not cause a change in learning approach as defined in the Lancaster learning approach questionnaire.

\section{Hypothesis}

Computer-based teaching improves knowledge and problem-solving and influences learning approaches.

\section{RESEARCH METHOD, DESIGN AND TECHNIQUES}

The quantitative research method with a comparative and descriptive design was selected. The design included an experimental and pre-test-post-test control group.

Research techniques used were a literature review and six measuring instruments. The six measuring instruments were used to gather data, and to test the hypotheses. The instruments included the following:

- a computer-based data collection programme;

- a Lancaster learning approach and course evaluation questionnaire;

- a pre- and post-test consisting of multiple choice test items;

- a pre- and post-test consisting of a case study; 
and

- a guideline and coding form for evaluating the case study and assessing problem-solving.

The computer-based data collection programme was developed by an expert to obtain specific data. The latter five instruments were developed by the researcher. The use, validity and reliability of the instruments will be briefly discussed.

\section{Validity, reliability and data gathering with respect to the CBTP}

\section{Computer-based data collection pro- gramme}

Certain data, such as the time and date on which the CBTP was used, which respondent used it, and which content was studied, were gathered with the help of a programme written for this purpose. Comparisons were ultimately drawn between the utilisation of the CBTP, the students' learning approaches and their knowledge.

\section{The Lancaster learning approach and course evaluation questionnaire}

The Lancaster learning approach and course evaluation questionnaire was developed with the aim of evaluating how students at tertiary institutions learn and how they experience their course. The instrument was developed by the Lancaster University (UK) and used in a national survey on students' approaches to learning. The Lancaster approach has been used since at various universities, among others in Australia and South Africa.

Both control and experimental groups completed two Lancaster learning approach questionnaires. The first test was completed at the start of the respondents' participation in the research, and the second at the end of two months in the oncology department (practical group) or after six hours in a multimedia centre (multimedia centre group). The six hours time limit for the MMC was determined once the researcher had calculated that students in the ward could spend at least 10 minutes per clinical practice session on the CBTP. The aim of the Lancaster questionnaire was to evaluate nil hypothesis 3 that has to do with the effect of the CBTP on respondents' learning approaches.

As far as the validity of the questionnaires is concerned,
Ramsden (1983:13) provides various reasons as to why it can be accepted with reasonable certainty that the Lancaster approach measures what it is meant to measure. The Chronbach alpha values that were obtained are indicated in the relevant guide. Although the values for some subscales may appear low, the joint values for each scale are acceptable according to Ramsden.

\section{The multiple choice pre- and post-test items}

Respondents in the control and experimental groups completed the pre-test at the start of their participation in the research. The practice group was subjected to the post-test at the end of two-months' exposure to oncology nursing and/or the CBTP and that of the multimedia group after six hours' use of the CBTP. The aim of the multiple choice pre-and post test was to evaluate Hypothesis 1, which reads that computerbased teaching improves knowledge.

The thirty multiple choice test items for the pre- and post-test were compiled out of the eighty-one test items included in the CBTP. The eight-one (81) items were evaluated by three experts with a post-basic diploma in nursing education in order to establish whether all levels of Bloom's taxonomy were taken into account during the drawing up of the multiple choice items.

Finally, the thirty questions of the pre- and post-test were evaluated by experts in the field of oncology nursing for content and scope validity. No corrections were necessary in view of their feedback and the content and scope validity of the tests were accepted on the basis of the consistency of the evaluation and feedback.

Both evaluations were taken into account and it was accepted that the multiple choice test items measure students' knowledge of oncology nursing and were thus reliable.

The reliability of the test was not statistically established on the basis of the alpha-coefficient, as the items or criteria that were included did not pertain to a specific construct. The statistical calculation of reliability was not significant according to a conversation with experts in this field at the university. The possibility of a re-test after two weeks was considered in order to establish 
reliability. Due to the scope of the research, and logistic problems concerning the implementation of such a step, it was decided that its omission would not have a negative influence on the study.

\section{The problem-solving (case study) pre- and post-test}

The case study was used to establish whether students' ability to solve nursing problems improved.

The ability to solve patient care problems is a very important skill of student nurses. In the nursing profession, after all relevant data have been obtained from the patient, problems are dealt with by means of the nursing process. The pre- and post-test used in this study were compiled after interviews with four patients, with the aim of ultimately selecting a suitable case study. The interview with the patients was conducted on the basis of a structured questionnaire.

All the respondents were given the data of the patient used in the case study.

A form was designed on which respondents in the control and experimental groups drew up the nursing care plan. The form made provision for the filling in of nursing diagnoses, related factors, defining characteristics and nursing actions. Each respondent received four copies of this form, on which to complete the nursing care plan.

\section{Guideline and coding form}

A guideline to evaluate the respondents' nursing care plans was drawn up to ensure the consistent revision of plans. The guideline included real and potential problems, related factors, defining characteristics and relevant nursing actions.

An evaluation instrument was also designed and used to assign a mark for respondents' nursing care plans.

Students were given full instructions regarding the compilation of the plan. They were expected to:

- study the case study,

- identify four real and four potential problems, and

- formulate four nursing actions for each problem. order to establish the validity of the content of the case study and the guideline for evaluating the nursing care plan, the case study and the guideline were evaluated by the same experts in oncology nursing who assessed the pre- and post-test items. The part of the case study regarding the background of the patient was amended on the basis of their feedback and included a few nursing actions which were better suited to the particular department. The validity of the content of the case study and the guideline were thus controlled and it was also accepted that the nursing care plans that students were to draw up would give an indication of their ability to identify and solve nursing problems.

As in the case of the reliability of the multiple choice pre- and post-test items, the reliability of the problemsolving (case study) pre- and post-test was not established.

\section{DATA ANALYSIS}

Two sets of data, namely those with respect to the practice and multimedia centre group (hereafter referred to as MMC group) were available for analysis.

As the data were not distributed in the normal manner, and research groups sometimes consisted of very few observations, they were described in frequencies or percentages and medians. Non-parametric methods, for instance non-parametric confidence intervals, Mann-Whitney tests, Wilcoxon's sign rank test for accompanying data were used to establish whether differences were statistically significant. Spearman correlation coefficients were also taken into account. The confidence intervals were evaluated to establish whether the differences were clinically significant.

The data of the practice and MMC groups are discussed separately and comparisons are drawn between the two groups. (They will be referred to throughout as practice, MMC and practice and MMC groups).

The response rate to the multiple choice test items, problem-solving and Lancaster learning approach questionnaire for pre- and post-tests was established in order to obtain an overview of the extent to which respondents took part in the research. The response rate ranged between $82.5 \%$ and $100 \%$.

The data are discussed on the basis of the specific hypotheses and research objectives. 


\section{Computer-based sessions, time spent and knowledge}

A discussion follows of the effect of the CBTP on respondents' knowledge of oncology nursing, as established by a pre- and post-test.

The difference (post-scoring-pre-scoring) was calculated for each respondent in the experimental and control groups of both the practice, and MMC groups. Wilcoxon's sign rank test and non-parametric confidence intervals were used to establish whether the differences, if they were positive, indicated an improvement and were statistically significant.

A statistically significant difference between two groups was accepted if $p<0.05$ and the confidence interval excluded the value 0 .

\section{Number of sessions and time spent} Multimedia group - experimental $(n=20)$ and practice group - experimental $(n=40)$

The MMC group in general made more use of the CBTP than the practice group. The median sessions were 3 (practice) and 12 (MMC).

The difference in the median time spent on a session was (1.9 minutes: practice against 8.5 minutes: $M M C$ ).

\section{Scores of students on knowledge}

Data regarding the knowledge of both $\mathrm{MMC}$ and practice groups (experimental and control) about the multiple choice test items were analysed, first separately and then together. The $(n=)$ value in the respective groups differs as respondents who did not complete their pre- and post-tests were considered missing. If the data of any two paired respondents were missing, both their data were omitted from the analysis.

In the multiple choice test item section, respondents could obtain a maximum of 43 marks. It seems that the post-scores of respondents on the multiple choice test items were better than the scores on their pretests. The median for the post-scores of the experimental group (MMC) was 35.5 and 17 for the practice group. The median of the control group (MMC) on their post-score was 15.5 and 12.5 on their pre-score.

The minimum and maximum points for the pre-tests of all groups ranged between 5 and 11 and 19 and 27 points. The minimum and maximum for the post-tests of all groups ranged between 6 and 17 and 35 and 40 . It would seem that there was a great improvement in the maximum of the experimental group (practice), experimental group (MMC) and experimental group (practice and MMC).

Wilcoxon's sign rank test for paired differences (postpre) and non-parametric confidence intervals were used to establish whether this improvement was significant (see Table 1). As there was an improvement in both the experimental and control groups, it was necessary to establish whether the improvement in the experimental group was of greater statistical significance greater than in the control group. The experimental (post-pre) -control (post-pre) score were calculated for this purpose. Table 1 is on next page.

The median differences in the experimental group were 4 (practice) and 17 (MMC) and 7.5 (practice and MMC). On the other hand, the median differences for the control groups were 1 (practice) and 3 (MMC) and 1 (practice and MMC).

The experimental groups (practice, and practice and $\mathrm{MMC}$ ) obtained the maximum improvement: 25 points for the post-test. Twenty-five per cent of the experimental group (MMC) obtained 22 points and more on their post-test and $25 \%$ in the control group (MMC) obtained 6.5 points more on their post-tests. In the experimental (post-pre) - control (post-pre) (MMC) 25\% of respondents obtained 16 points and more on their post-tests and $25 \%$ respondents obtained 9 points and less on their post-tests.

Although there was a statistically significant improvement in the experimental and control group (MMC), it is apparent from the comparison of these that the improvement in the experimental group is of greater statistical significance greater than the improvement in the control group, with $95.1 \% \mathrm{VI}[9 ; 16]$.

It can be stated with $95.1 \%$ certainty that, should the study be repeated, the experimental group (MMC) will obtain a score between 12 and 22 points higher on their post-tests. The experimental group (practice) will obtain between 2 and 8 points more with $95.6 \%$ certainty. 
Table 1: Description of the differences in scores in respect of multiple choice items (post-pre) practice, MMC, practice and MMC group

\begin{tabular}{|c|c|c|c|c|c|c|c|c|c|}
\hline $\begin{array}{l}\text { GROUP (POST- } \\
\text { PRE) }\end{array}$ & $\mathbf{N}$ & 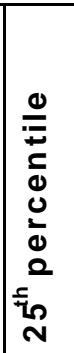 & 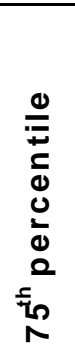 & $\begin{array}{l}\frac{c}{\pi} \\
\frac{\pi}{0} \\
0 \\
\Sigma\end{array}$ & $\stackrel{\Sigma}{\Sigma}$ & $\begin{array}{l}\underset{\pi}{\pi} \\
\Sigma\end{array}$ & 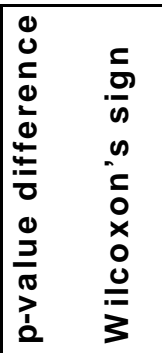 & 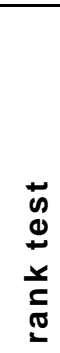 & 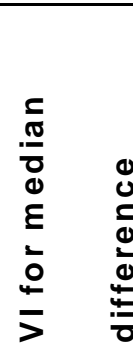 \\
\hline $\begin{array}{l}\text { Practice } \\
\text { Experimental }\end{array}$ & 35 & 0 & 10 & 4 & -9 & 23 & $<0.01^{* *}$ & & $\begin{array}{l}95.6 \% \\
2 ; 8\end{array}$ \\
\hline Control & 38 & -2 & 3 & 1 & -7 & 22 & \begin{tabular}{|l|}
0.67 \\
\end{tabular} & & $\begin{array}{l}96.6 \% \\
-1 ; 2\end{array}$ \\
\hline $\begin{array}{l}\text { Experimental } \\
\text { Control }\end{array}$ & 33 & -2 & 10 & 3 & -10 & 25 & $<0.01^{*}$ & & $\begin{array}{l}96.5 \% \\
0 ; 9\end{array}$ \\
\hline $\begin{array}{l}\boldsymbol{M} \boldsymbol{M C} \\
\text { Experimental }\end{array}$ & 17 & 12 & 22 & 17 & 4 & 24 & $<0.01^{\text {** }}$ & & $\begin{array}{l}95.1 \% \\
12 ; 22\end{array}$ \\
\hline Control & 20 & 1 & 6.5 & 3 & -2 & 13 & $<0.01^{* *}$ & & $\begin{array}{l}95.9 \% \\
1 ; 6\end{array}$ \\
\hline $\begin{array}{l}\text { Experimental } \\
\text { Control }\end{array}$ & 17 & 9 & 16 & 14 & -9 & 22 & $<0.01^{* *}$ & & $\begin{array}{l}95.1 \% \\
9 ; 16\end{array}$ \\
\hline $\begin{array}{l}\text { Practice and } \\
M \boldsymbol{M C} \\
\text { Experimental }\end{array}$ & 52 & 2 & 16 & 7.5 & -9 & 24 & $<0.01^{* *}$ & & $\begin{array}{l}96.4 \% \\
4 ; 14\end{array}$ \\
\hline Control & 58 & 0 & 3 & 1 & -7 & 22 & $0.01^{*}$ & & $\begin{array}{l}95.2 \% \\
0 ; 2\end{array}$ \\
\hline $\begin{array}{l}\text { Experimental } \\
\text { Control }\end{array}$ & 50 & 0 & 15 & 7.5 & -10 & 25 & $<0.01^{* *}$ & & $\begin{array}{l}96.7 \% \\
3 ; 11\end{array}$ \\
\hline
\end{tabular}

**: Highly significant

*: $\quad$ Significant

VI: Non-parametric confidence interval 
In terms of various confidence intervals, the difference of $12 ; 22$ and $9 ; 16$ points (MMC) and 11 to 14 points (practice and $\mathrm{MMC}$ ) may be considered a clinically significant improvement.

Spearman's correlation coefficient indicated that there was no connection between any respondents' difference in scores on their multiple choice test items (postpre) and the time or number of sessions they spent on the CBTP.

\section{Computer-based sessions, time spent and problem-solving (case study)}

This study also attempted to develop respondents' ability to solve nursing care problems by means of a CBTP.

A full exposition of the nursing process was provided in the CBTP and the extent to which respondents utilised this was monitored by means of a computer programme written for that purpose.

\section{Number of sessions and time spent} Practice group - experimental: $(n=40)$

The median number of sessions for problem-solving was three. One respondent used 20 sessions to become au fait with the content of this section.

The median time spent on this section was $3.8 \mathrm{~min}-$ utes. One respondent spent 79.85 minutes to obtain more information about the nursing process.

\section{Multimedia group - experimental: $(n=20)$}

Four respondents did not take the trouble to consult the section dealing with the process of nursing. The section was designed to guide students in the process of problem-solving. The median number of sessions was three. One respondent spent eleven while another spent nine sessions on this task. The highest frequency was four respondents (20\%) who utilised four sessions.

The time spent by the multimedia group on this section ranged from 0.53 to 73.3 minutes with a median of 19.1 minutes. Eleven respondents (55\%) spent between 0.53 and 28.45 minutes to master the content.

\section{Scores of students for problem-solving}

The scores of respondents for problem-solving consisted of their points for the identification of real and potential problems. Their total scores were calculated by adding the scores for the real and potential problems and the difference between post- and pre-scores was calculated.

As there was no improvement in the scores of either the experimental or control groups, a comparison was not drawn between them.

As can be deduced from Table 2, the difference between respondents in post- and pre-scores will vary as follows, should tests be repeated:

\section{Practice group (experimental) (97.6\% certainty)}

- real problems $(-1 ; 7)$; potential problems $(-3 ; 10)$; total score 13).

MMC group (experimental) (95.1\% certainty)

- real problems $(2 ; 19)$; potential problems $(-2 ; 9)$; total score $(2 ; 27)$.

Practice and MMC group (experimental) (95.1\% certainty)

- real problems $(1 ; 9)$; potential problems $(0 ; 7)$; total score $(3 ; 17)$.

These scores mean, for instance, that if a respondent in the practice group obtained an improvement of 20 on the real problems, the improvement upon retesting may vary between 19 (20-1) and 27 (20+7). A similar interpretation holds for the MMC and the practice and MMC groups. Table 2 is on opposite page.

In general, however, the score of respondents for problem-solving improved. In the experimental group (practice) $25 \%$ obtained up to 19 points more on their posttests (total). Nine respondents obtained between 1840 points more on their post-tests. Some respondents in the control group (practice) obtained up to 11 points more on their pre-tests on real problems. The scores of experimental and control (MMC) respondents who fared better in their pre-tests ranged between 2 and 10 points.

To the researcher the improvement that can occur according to the various confidence intervals, that is, ex- 
perimentalgroups (practice, $\mathrm{MMC}$, practice and $\mathrm{MMC}$ ) real problems between 7 and 19 points, the experimental group (practice) potential problems 10 points, and the improvement on the total score (practice, MMC, practice and $\mathrm{MMC}$ ) respectively 13,27 and 17, is clinically significant.

The nil hypothesis, as far as the scores of the practice group, experimental (post-pre), control group (postpre), and the experimental (post-pre) -control (postpre) are concerned, cannot be rejected. This means that computer-based teaching made no difference to respondents' knowledge regarding problem-solving. The p-values calculated according to Wilcoxon's sign rank test for paired data were not statistically significant.

In respect of the MMC group, the nil hypothesis in the case of respondents' scores on potential problems is not rejected, but it is rejected in the case of respondents' scores on real problems and their final score on problem-solving. The scores of respondents on real problems, as well as their total score for problem-solving, however, showed statistically significant differences. The p-values according to Wilcoxon's sign rank test were smaller than 0.01 in these cases. According to the confidence interval the improvement in total score can be up to 27 points, which is clinically significant.

There were also statistically significant differences where the scores of the practice and MMC group were combined. However, it would seem that the scores of the MMC group were largely responsible for these differences. In respect of the real problem and the total on problem-solving, the nil hypothesis must be rejected. The scores that these two groups obtained on potential problems almost indicated a statistically significant difference $(p=0.05[95.1 \% 0 ; 7])$.

The researcher also wanted to establish whether there is any connection between the scores which respondents obtained on problem-solving (post-pre) and the number of sessions and time spent. The Spearman correlation coefficient was used here because data were not normally distributed.

It seems that the nil hypothesis, namely that the time and number of sessions spent on the CBTP will not improve the problem-solving skill of respondents, can- not be rejected.

\section{Computer-based teaching and learning approaches}

The learning approach of students was established by means of the Lancaster learning approach questionnaire. The total score that respondents could obtain on the various categories of the Lancaster are as follows: Significance-orientation [64]; reproduction-orientation [64]; non-academic orientation [48]; and strategic orientation [48].

\section{Influence on learning approach}

The percentage (minimum and maximum) scored by the respondents in clinical practice on learning approaches ranged between $39.06 \%$ and $93.75 \%$ (significance orientation), and $14.58 \%$ to $77.08 \%$ (nonacademic orientation). The lowest percentage obtained on reproduction was $37.5 \%$ and the highest was $90.63 \%$. The percentage scored by respondents on strategic orientation ranged from $43.75 \%$ to $85.42 \%$.

In the MMC group's percentages ranged between $40.63 \%$ and $85.94 \%$ (significance orientation), $26.56 \%$ to $73.44 \%$ (reproduction orientation), $12.5 \%$ to $70.83 \%$ (non-academic orientation) and $43.75 \%$ to $83.33 \%$ (strategic orientation).

The percentages of respondents in clinical practice and the MMC group were $39.06 \%$ to $93.75 \%$ (significance orientation), $26.56 \%$ to $90.63 \%$ (reproduction orientation), $12.5 \%$ and $77.08 \%$ (non-academic orientation) and $43.75 \%$ to $85.42 \%$ (strategic orientation).

The median for the significance orientation was between $71.09 \%$ for the clinical practice and $65.62 \%$ for the MMC group and for reproduction orientation 53.91\% (MMC) and $63.28 \%$ (practice). As far as non-academic orientation is concerned the medians were, $41.67 \%$ (practice) and $34.38 \%$ (MMC) and the strategic orientation median was $66.67 \%$ (MMC) and $68.75 \%$ (practice). The highest median (71.9\%) occurred in the significance orientation (practice).

The scores obtained in pre- and post-tests are described by median and percentiles. The difference in percentage between pre- and post-tests was calculated and compared using Wilcoxon's sign rank test and con- 
Table 2: Scores (post and pre) and differences in scores (post-pre) obtained on problem-solving for the practice, MMC, practice and MMC groups

\begin{tabular}{|c|c|c|c|c|c|c|c|c|}
\hline GROUP & 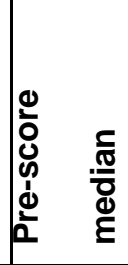 & 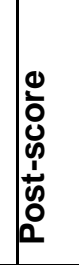 & 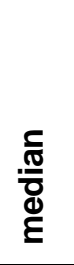 & 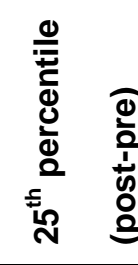 & 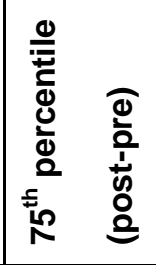 & 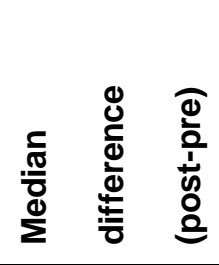 & 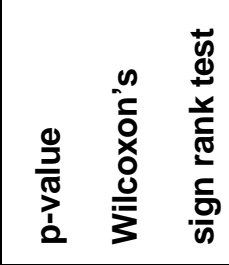 & 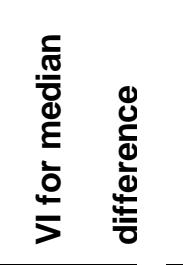 \\
\hline \multicolumn{9}{|l|}{ Practice } \\
\hline \multicolumn{9}{|l|}{$\begin{array}{l}\text { Experimental } \\
(\mathrm{N}=34)\end{array}$} \\
\hline - real & 28.5 & 31 & & -4 & 9 & 2.0 & 0.26 & $97.6 \%-1 ; 7$ \\
\hline - potential & 13.5 & 16. & & -4 & 13 & 1.5 & 0.19 & $\begin{array}{l}97.6 \% \\
-3 ; 10\end{array}$ \\
\hline- total & 43.5 & 50 & & -4 & 19 & 4.0 & \begin{tabular}{|l|}
0.07 \\
\end{tabular} & $\begin{array}{l}97.6 \% \\
2 ; 13\end{array}$ \\
\hline \multicolumn{9}{|l|}{$\begin{array}{l}\text { Control } \\
(\mathrm{N}=31)\end{array}$} \\
\hline - real & 26 & 25 & & -11 & 5 & -1 & 0.79 & $\begin{array}{l}97.1 \% \\
-9 ; 4\end{array}$ \\
\hline- potential & 9 & 10 & & $\frac{-3}{-3}$ & 7 & 0 & \begin{tabular}{|l|l|}
0.48 \\
\end{tabular} & $\begin{array}{l}97.1 \% \\
-2 ; 4\end{array}$ \\
\hline- total & 35 & 38 & & -10 & 13 & 0 & 0.69 & $\begin{array}{l}97.1 \% \\
-2 ; 5\end{array}$ \\
\hline \multicolumn{9}{|l|}{$M M C$} \\
\hline \multicolumn{9}{|l|}{$\begin{array}{l}\text { Experimental } \\
(\mathrm{N}=17)\end{array}$} \\
\hline- real & 26 & 42 & & 2 & 19 & 12 & $<0.01^{* *}$ & $\begin{array}{l}95.1 \% \\
2 ; 19\end{array}$ \\
\hline - $\quad$ potential & 22 & 20 & & -2 & 9 & 3 & 0.09 & $\begin{array}{l}95.1 \% \\
-2 ; 9\end{array}$ \\
\hline- total & 49 & 65 & & 2 & 18 & 27 & $<0.01^{* *}$ & $\begin{array}{l}95.1 \% \\
2 ; 27\end{array}$ \\
\hline Control & & & & & & & & \\
\hline
\end{tabular}




\begin{tabular}{|c|c|c|c|c|c|c|c|}
\hline- real & 35 & 34 & -5 & $\overline{-1}$ & 8 & 0.88 & $\begin{array}{l}98.1 \% \\
-5 ; 8\end{array}$ \\
\hline - potential & 19 & 26 & -4 & 10 & 0 & 0.37 & $\begin{array}{l}98.1 \% \\
-4 ; 10\end{array}$ \\
\hline- total & 52 & 60 & -10 & 6 & 12 & 0.50 & $\begin{array}{l}98.1 \% \\
-10 ; 12\end{array}$ \\
\hline $\begin{array}{l}\text { Practice and } \\
\text { MMC }\end{array}$ & & & & & & & \\
\hline $\begin{array}{l}\text { Experimental } \\
(\mathrm{N}=51)\end{array}$ & & & & & & & \\
\hline- real & 27 & 37 & -2 & 15 & 4 & $<0.01^{* *}$ & $\begin{array}{l}95.1 \% \\
1 ; 9\end{array}$ \\
\hline - potential & 17 & 19 & -3 & 11 & 2 & 0.05 & $\begin{array}{l}95.1 \% \\
0 ; 7\end{array}$ \\
\hline$-\quad$ total & $\overline{47}$ & 56 & -2 & 23 & 6 & $<0.01^{* *}$ & $\begin{array}{l}95.1 \% \\
3 ; 17\end{array}$ \\
\hline Control & & & & & & & \\
\hline- real & 30.5 & 28.5 & -9 & 5 & -1 & 0.7 & $\begin{array}{l}96.7 \% \\
-4 ; 3\end{array}$ \\
\hline - potential & 10 & 15.5 & -3 & 8 & 0 & 0.23 & $\begin{array}{l}96.7 \% \\
0 ; 3\end{array}$ \\
\hline- total & 39.5 & 46 & -10 & 12 & 0 & 0.48 & $\begin{array}{l}96.7 \% \\
-2 ; 6\end{array}$ \\
\hline
\end{tabular}

** Highly significant

* Statistically significant

fidence intervals for non-parametric data. If respondents' percentage on the categories significance and strategic increased, this indicates a positive change in learning approach. A low percentage or a decrease in percentage in respect of the categories reproduction and non-academic is also considered to be good. This would indicate that respondents in this case tend more towards a deeper approach. The difference between experimental (post-pre) and control (post-pre) was cal- culated in this case too. Table 3 on next page.

The minimum score obtained on the pre-tests was one (non-academic, practice and practice and MMC). The maximum pre-score was 60 (total 64) obtained for significance orientation (practice and practice and MMC).

The minimum and maximum scores on the post-tests were one (1) (non-academic, practice and practice and 
Table 3: Description of pre- and post-scores with respect to the Lancaster learning approach for the practice, MMC, practice and MMC groups

\begin{tabular}{|c|c|c|c|c|c|c|c|c|c|c|}
\hline GROUP & 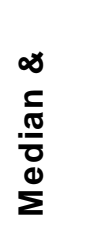 & 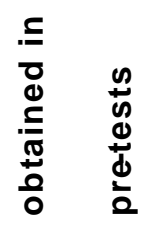 & $\stackrel{\Sigma}{\Sigma}$ & 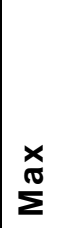 & z & $\begin{array}{l}\circ \\
\frac{0}{\sigma} \\
\frac{\pi}{0} \\
\frac{0}{\Sigma} \\
\Sigma\end{array}$ & 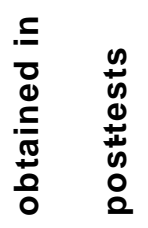 & $\stackrel{\Sigma}{\Sigma}$ & $\sum_{\Sigma}^{\mathbb{x}}$ & z \\
\hline \multicolumn{11}{|l|}{ Practice } \\
\hline \multicolumn{11}{|l|}{ Experimental } \\
\hline - $\quad$ significance & 45.5 & & 25 & 60 & 38 & 47 & & 23 & 61 & 35 \\
\hline - $\quad$ reproduction & 40.5 & & 24 & 58 & 38 & 38 & & 21 & 56 & 35 \\
\hline - $\quad$ non-academic & 20 & & 7 & 37 & 38 & 19 & & 1 & 53 & 35 \\
\hline - $\quad$ strategic & 33 & & 21 & 58 & 38 & 31 & & 10 & 45 & 35 \\
\hline \multicolumn{11}{|l|}{ Control } \\
\hline $\begin{array}{ll}- & \text { significance }\end{array}$ & 41 & & 28 & 58 & 37 & 41.5 & & 19 & 59 & 40 \\
\hline - $\quad$ reproduction & 39 & & 23 & 54 & 37 & 35.5 & & 16 & 52 & 40 \\
\hline- non-academic & 21 & & 1 & 34 & 37 & 21 & & 8 & 34 & 39 \\
\hline $\begin{array}{ll}- & \text { strategic }\end{array}$ & 30 & & 18 & 42 & 37 & 29 & & 16 & 46 & 40 \\
\hline \multicolumn{11}{|l|}{$M M C$} \\
\hline \multicolumn{11}{|l|}{ Experimental } \\
\hline - $\quad$ significance & 42 & & 26 & 55 & 20 & 43.5 & & 28 & 56 & 18 \\
\hline - reproduction & 34 & & 17 & 47 & 20 & 31 & & 19 & 49 & 18 \\
\hline- non-academic & 16.5 & & 6 & 34 & 20 & 15.5 & & 5 & 35 & 18 \\
\hline - $\quad$ strategic & 32 & & 21 & 40 & 20 & 30 & & 20 & 43 & 18 \\
\hline \multicolumn{11}{|l|}{ Control } \\
\hline - $\quad$ significance & 43.5 & & 33 & 51 & 20 & 42 & & 8 & 55 & 19 \\
\hline - $\quad$ reproduction & 38 & & 19 & 53 & 20 & 37.5 & & 20 & 52 & 18 \\
\hline$-\quad$ non-academic & 20.5 & & 9 & 37 & 20 & 19 & & 4 & 42 & 19 \\
\hline $\begin{array}{ll}- & \text { strategic }\end{array}$ & 31.5 & & 14 & 40 & 20 & 30 & & 7 & 39 & 19 \\
\hline \multicolumn{11}{|l|}{ Practice and MMC } \\
\hline \multicolumn{11}{|l|}{ Experimental } \\
\hline - $\quad$ significance & 45 & & 25 & 60 & 58 & 44 & & 23 & 61 & 53 \\
\hline
\end{tabular}




\begin{tabular}{|c|c|c|c|c|c|c|c|c|}
\hline - reproduction & 39 & 17 & 58 & 58 & 37 & 19 & 56 & 53 \\
\hline - $\quad$ non-academic & 18 & 6 & 37 & 58 & 18 & 1 & 53 & 53 \\
\hline - $\quad$ strategic & 32 & 21 & 58 & 58 & 31 & 10 & 45 & 53 \\
\hline \multicolumn{9}{|l|}{ Control } \\
\hline - $\quad$ significance & 43 & 28 & 58 & 57 & 42 & 8 & 59 & 59 \\
\hline - $\quad$ reproduction & 38 & 19 & 54 & 57 & 36.5 & 16 & 52 & 58 \\
\hline - $\quad$ non-academic & 21 & 1 & 37 & 57 & 20 & 4 & 42 & 58 \\
\hline $\begin{array}{ll}- & \text { strategic }\end{array}$ & 30 & 14 & 42 & 57 & 29 & 7 & 46 & 59 \\
\hline
\end{tabular}

$\mathrm{MMC}$ ) and 61 (significance orientation, practice and practice and $\mathrm{MMC}$ ).

The medians for the pre- vs the post-tests were, as far as significance orientation is concerned, respectively (45.5-47: practice), (42-43.5: $M M C$ ) and (45-44: practice and $M M C)$. The medians for the strategic orientation experimental groups were respectively (33-31), (32$30)$ and (18-18). Medians for significance orientation were as follows: (control groups) (41-41.5), (43.5-42) and (43-42). As far as reproduction and non-academic orientation are concerned, the median either remained constant (21-21: non-academic) or changed as follows (40.5-38: reproduction), (20-19: non-academic), 3431: reproduction).

The median differences in the above table indicate that in some instances a higher percentage was obtained on the pre- than on the post-test. The highest percentage on pre-tests was 2.5 .

Wilcoxon's sign rank test as well as the confidence intervals for non-parametric data did not indicate any statistically significant difference. Nil hypothesis 3, which states that computer-based teaching does not lead to a change in learning approach, cannot be rejected.

\section{CONCLUSIONS AND RECOMMENDA- TIONS}

The following conclusions and recommendations are important.

\section{Response rate}

The response rate of respondents on the various preand post-tests, that is, multiple choice test items, problem-solving, and the Lancaster learning approach questionnaire, ranged from $82.5 \%$ to $100 \%$. This response rate may be considered good in general, but the fact that respondents were paired in experimental and control groups meant that some respondents' data could not be included in an analysis if one partner's data were incomplete. This resulted in fewer observations than initially planned, thereby influencing statistical significance.

\section{Computer-based sessions, time spent and knowledge}

The practice group had the opportunity to utilise the CBTP over a period of two months, whereas the MMC group were given 6 hours to acquire knowledge. The difference in the median sessions (3 practice and 12 MMC) may possibly be ascribed to the fact that the MMC group completed the research under very strict controlled circumstances. The extent to which the practice group utilised the CBTP could possibly be influenced by internal factors such as a shortage of staff, patient loads, the nursing care needs of patients, and also the fact that staff strikes took place during the implementation of the research.

The difference in the median time spent on a session (1.9 minutes: practice against 8.5 minutes: MMC) may possibly also be ascribed to the fact that respondents 
used the CBTP under different circumstances.

It would seem that controlled circumstances such as those to which the MMS group was exposed had a better effect. The median improvement of the experimental group (MMC) on the multiple choice test items was 17 against the 4 points of the experimental group (practice). It is apparent from the confidence interval that the improvement could be as much as 22 points. The increase of 3 in the post-scores of the control group (MMC) may possibly be ascribed to the fact that respondents in this group were allowed to utilise relevant sources. The increase amongst respondents in the control group (practice) was not significant.

The Spearman correlation coefficient used to establish whether the time and number of sessions spent had any effect on respondents' knowledge indicated no connection in this respect.

The findings that CBTP improves knowledge are in line with research findings in this respect. This do-it-yourself teaching module must, however, as confirmed by other research, be backed by inputs from the lecturer.

\section{Computer-based sessions, time spent and problem-solving}

The median sessions were 3 for both the practice and the MMS group. The time spent by the practice and MMS group was 3.8 and 19.17 .

There was a statistically significant difference (Mann Whitney $p<0.01)$ in time spent on the section on problem-solving between the practice and MMS groups. This difference may possibly be due to the fact that respondents in the MMC group felt more obliged to use this section than the practice group did.

Although the MMC group spent more time on this section, there was no statistically significant connection between respondents' score on problem-solving and time spent.

\section{The effect of CBTP on respondents' learn- ing approach}

There was no statistically significant change in respondents' learning approaches (Lancaster) upon utilising the CBTP in any of the groups. There were slight differences in respect of the various categories of the learning approach (significance, reproduction, nonacademic, and strategic). If respondents' scores on the significance and strategic categories improved, it was considered a positive improvement in learning approach. A drop in scores on the reproduction and nonacademic categories meant that respondents rather

followed a deep approach. There was no improvement in scores in the strategic category.

\section{RECOMMENDATIONS}

If the training objective is to promote student nurses' knowledge of oncology nursing care, it is recommended that this section on multiple choice test items, in which the necessary information regarding four cancer conditions (carcinoma of the breast, lung, oesophagus and cervix) is included, be used as an independent work session.

An advantage of this section is that student nurses receive immediate feedback on their progress. If this is used in practice, student nurses can, independently of the inputs of ward staff or clinical lecturers, acquire considerable knowledge. The way in which the section is presented is also interesting and should serve as motivation to learn more about oncology nursing care. In this respect the CBTP can be used as effectively in practice as in a multimedia set-up.

The section on problem-solving can also be used as an independent work session. Student nurses who are faced with the nursing process for the first time should benefit from this. If the information about the nursing process is consulted in the practice setting, the information should be valuable to ensure scientific care.

This study indicates that student nurses experience problems in identifying potential problems. It seems that the CBTP does not actually promote this ability. It is recommended that a tutorial supplementing the independent session be used. Student nurses should also be guided until they have the necessary skills to identify potential problems and they should be encouraged to utilise the section as often as possible.

The effect of the CBTP on learning approaches may 
possibly be better evaluated if the number of respondents was to be increased and they were given more time to utilise the CBTP.

\section{REFERENCES}

BOUCHER, B; HUNTER, D \& HENRY, J 1999: The effectiveness of computer-assisted instruction in teaching biomechanics of the temporomandibular joint. Journal of Physical Therapy Education, 13(2):47-51.

BOVE, LA 2000: Computer-assisted education for critical care nurses. Critical Care Nursing Clinics of North America, 13(1):73-81.

CRONJE, J 1994: Hypermedia and contemporary learning theory. (In: Hypermedia '94. $2^{\text {nd }}$ Southern African conference on multimedia and hypermedia. Pretoria: March, pp. 47-51.)

ENTWISTLE, NJ 1981: Styles of learning and teaching. An integrated outline of educational psychology for students, teachers and lecturers. New York: John Wiley \& Sons.

ENTWISTLE, NJ 1984: Contrasting perspectives on learning. (In: Marton, F; Hounsell, D \& Entwistle, NJ 1984: The experience of learning. Edinburgh: Scottish Academic Press.)

ENTWISTLE, NJ \& Meyer, JHF 1992: Findings and implications from research on student learning. South African Medical Journal, June, 81:593-595.

KRULIK, S \& RUDNICK, JA 1984: A sourcebook for teaching problem-solving. London: Allyn and Bacon, Inc.

LYONS, J; MILLER, M \& MILTON, J 1998: Learning with technology: Use of case-based physical and computer simulations in professional education. Contemporary Nurse, 7(1):35-39.

MANIAS, E; BULLOCK, S \& BENNETT, R 1999: A computer-assisted learning program in pharmacology: Integrating scientific and nursing knowledge. Contemporary Nurse, 8(2):23-29.

MANIAS, E; BULLOCK, S \& BENNETT, R 2000: Formative evaluation of a computer-assisted learning program in pharmacology for nursing students. Computer in Nursing, 18(6):265-271.

MARTENSON, DF 1986: Students' approaches to studying in four medical schools. Medical Education, 20:532-534.

MARTON, F; HOUNSELL, D \& ENTWISTLE, N 1984: The experience of learning. Edinburgh: Scottish Academic Press.

MARTON, F \& SäLJO, R 1984: Approaches to learning. (In: Marton, F; Hounsell, D \& Entwistle, N 1984: Experience of learning. Edinburgh: Scottish Academic Press.)

McKANE, CL \& SCHUMACHER, L 1997: Professional advancement model for critical care orientation. Journal of Nursing Staff Development, 13(2):88-91.

NEWBLE, DI \& ENTWISTLE, NJ 1986: Learning styles and approaches: implications for medical education. Medical Education, 20:162-175.
NORMAN, GR 1988: Problem-solving skills, Solving problems and problem-based learning. Medical Education, 22:279-286.

NORMAN, GR; TUGWELL, P; FEIGHTNER, JW; MUZZIN, LJ \& JACOBY, LL 1985: Knowledge and clinical problem-solving. Medical Education, 19:344-356.

RAMSDEN, P 1983: The Lancaster approaches to studying and course perceptions questionnaire: Lecturers handbook. Oxford: Polytechnic.

RIDDERIKHOFF, J 1991: Medical problem-solving: An exploration of strategic. Medical Education, 25:196-207.

SABA, VK \& McCORMICK, KA 1986: Essentials of computers for nurses. Philadelphia: Lippincott.

TUMA, DT \& REIF, F 1980: Problem-solving and education: Issues in teaching and research. London: Lawrence Erlbaum Associates, Publishers.

VAN HOOZER, HL; BRATTON, BD; OSTMOE, PM; WEINHOLTZ, D; CRAFT, MJ; GJERDE, CL \& ALBENESE, MA 1987: The teaching process: Theory and practice in nursing. Norwalk: AppletonCentury-Crofts. 